\title{
Production of Methane Emissions from Ruminant Husbandry: A Review
}

\author{
Jan Broucek \\ National Agricultural and Food Centre, Research Institute of Animal Production Nitra, Luzianky, Slovakia \\ Email: broucek@vuzv.sk
}

Received 28 August 2014; revised 24 September 2014; accepted 18 October 2014

Copyright (C) 2014 by author and Scientific Research Publishing Inc. This work is licensed under the Creative Commons Attribution International License (CC BY). http://creativecommons.org/licenses/by/4.0/

(c) (i) Open Access

\section{Abstract}

The aim of this review is to summarize the current knowledge of methane $\left(\mathrm{CH}_{4}\right)$ production from ruminants. The objectives are to identify the factors affecting $\mathrm{CH}_{4}$ production. Methane is a potent greenhouse gas (GHG). Ruminant livestock constitute worldwide the most important source of anthropogenic emissions of methane. There are two main factors influencing global warming change, an increase in greenhouse gas emissions and depletion of the ozone layer. Methane is associated with both factors. Ruminants (dairy, beef, goats, and sheep) are the main contributors to $\mathrm{CH}_{4}$ production. Their $\mathrm{CH}_{4}$ production is a natural and inevitable outcome of rumen fermentation. Feed is converted into products such as milk and meat. Many factors influence ruminant $\mathrm{CH}_{4}$ production, including level of intake, type and quality of feeds, energy consumption, animal size, growth rate, level of production, and environmental temperature. The methane emissions in dairy cows represent values from 151 to $497 \mathrm{~g} \cdot \mathrm{day}^{-1}$. Lactating cows produced more $\mathrm{CH}_{4}\left(354 \mathrm{~g} \cdot \mathrm{day}^{-1}\right)$

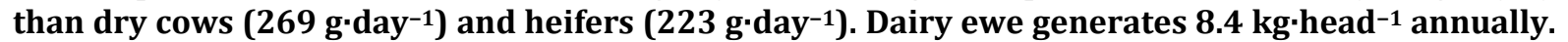
Holstein produced more $\mathrm{CH}_{4}\left(299 \mathrm{~g} \cdot \mathrm{day}^{-1}\right)$ than the Crossbred $\left(264 \mathrm{~g} \cdot \mathrm{day}^{-1}\right)$. Methane emission by heifers grazing on fertilized pasture was higher $\left(223 \mathrm{~g}^{-} \mathrm{day}^{-1}\right)$ than that of heifers on unfertilized pasture (179 g.day ${ }^{-1}$ ). The average $\mathrm{CH}_{4}$ emissions are from $161 \mathrm{~g} \cdot \mathrm{day}^{-1}$ to $323 \mathrm{~g} \cdot$ day $^{-1}$ in beef cattle. Mature beef cows emit $\mathrm{CH}_{4}$ approximately from $240 \mathrm{~g} \cdot \mathrm{day}^{-1}$ to $396 \mathrm{~g} \cdot \mathrm{day}^{-1}$. Suffolk sheep emit 22 $25 \mathrm{~g}$ day $^{-1}$. The bison's annual $\mathrm{CH}_{4}$ emissions per year were $72 \mathrm{~kg} \cdot \mathrm{head}^{-1}$. $\mathrm{The}^{\mathrm{CH}_{4}}$ emission from manure depends on the physical form of the feces, the amount of digestible material, the climate, and the time they remained intact. The annual emissions from the pens and storage pond at dairy farm were $120 \mathrm{~kg} \cdot \operatorname{cow}^{-1}$.

\section{Keywords}

Methane, Ruminants, Emissions, Dairy Cattle, Beef Cattle, Sheep 


\section{Introduction}

Agriculture is responsible for approximately $10 \%$ - 12\% of global anthropogenic greenhouse gases (GHG) emissions, excluding land use change [1] [2], particularly livestock is increasingly recognized as both a potential victim of it [3] [4]. Livestock is assumed to be responsible for the largest part at nearly $80 \%$ of total agricultural GHG emissions. This is particularly due to methane $\left(\mathrm{CH}_{4}\right)$ emissions from enteric fermentation and manure handling [5]-[7].

Methane is the major GHG produced from enteric fermentation during the normal digestive process of ruminants [8] [9]. It is important to note that production of greenhouse gases from animals and their impact on climate changes are a major concern worldwide [10] [11]. Production of GHG is often recalculated to production of carbon dioxide $\left(\mathrm{CO}_{2}\right)$ as carbon dioxide equivalent $\left(\mathrm{CO}_{2}-\mathrm{eq}\right)$, converted amounts of other gases to the equivalent amount of carbon dioxide with the same global warming potential. Cattle are considered to cause an increase in emissions with about $4.6 \mathrm{Gt}$ (gigatonnes) of $\mathrm{CO}_{2}$-eq, representing $65 \%$ of sector emissions. Average emission

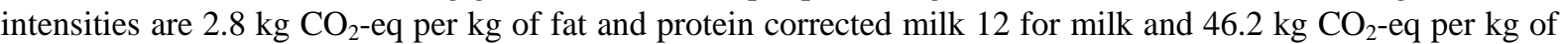
carcass weight for beef [12]. However, the current review will be devoted especially only to methane emissions.

\section{Generally about Methane}

Methane is one of the three main greenhouse gases, together with $\mathrm{CO}_{2}$ and nitrous oxide $\left(\mathrm{N}_{2} \mathrm{O}\right)$, its global warming potential is 25-fold than of $\mathrm{CO}_{2} \cdot \mathrm{CH}_{4}$ also affects the degradation of the ozone layer [3] [13]. Men are responsible for about two third of the total global $\mathrm{CH}_{4}$ emission called total anthropogenic methane [14]. Agriculture accounts for $47 \%$ - 56\% of total anthropogenic $\mathrm{CH}_{4}$ emissions [1] [15]-[17]. Of this amount may be $12 \%$ - 37\% of enteric origin [8] [10] [18] [19]. However, amount GHG percentages originating from enteric fermentation of ruminants often differ. While [20] indicated 87\%, [21] inform that enteric $\mathrm{CH}_{4}$ was the largest contributing source of GHG judging for $63 \%$ of total emissions. Study [8] indicated enteric $\mathrm{CH}_{4}$ was $12 \%$ of the global, $19 \%$ of the anthropogenic, and $36 \%$ of the agricultural $\mathrm{CH}_{4}$ emissions. Within the beef production cycle, the cow-calf system counted for about $80 \%$ of total GHG emissions and the feedlot system for only $20 \%$. About $84 \%$ of enteric $\mathrm{CH}_{4}$ was from the cow-calf herd, mostly from mature cows [21]. $10 \%$ to $15 \%$ of the total amount, which create ruminants, is formed from manure handling and storage [22]-[24].

Reference [25] reviewed literature sources and showed that the global enteric methane source was estimated in absolute values at $74 \mathrm{Tg}$ (teragrams) for 1982 year of which $74 \%$ were contributed by cattle and 8\% - 9\% by each of buffalo and sheep. According to [25], it was $84 \mathrm{Tg}$ for 1990 year, $80 \mathrm{Tg}$ for 1994 year, and $71 \mathrm{Tg}$, including $44 \mathrm{Tg}$ from grassland-derived feed, for 2003 year. There is a distinct difference in emission intensity between beef produced from dairy herds and from specialized beef herds. Related emissions amount to $1.1 \mathrm{Gt}$, representing $46 \%$ or $43 \%$ of the total emissions in dairy and beef supply chains, respectively [12].

Human-related methane emissions are mainly produced by domestic ruminants, rice fields, carbon mines, waste management, and natural gas usage [14]. In countries where agricultural activities are a major component of economy the contribution of $\mathrm{CH}_{4}$ to the total anthropogenic greenhouse gases emissions is comparable to the $\mathrm{CO}_{2}$ emissions. On the other hand, methane natural sources are mainly constituted by wetlands, including shallow marine water [26] [27]. Minor contributions come from termites and non-domestic ruminants [14]. Recent studies suggest that plants emit $\mathrm{CH}_{4}$ directly as a consequence of metabolic processes [14] [28].

Among animals, ruminants are the primary emitters of $\mathrm{CH}_{4}$. Their rumen, a large fore stomach, has a continuous fermentation system. The rumen occupies more than $70 \%$ of the total stomach capacity and its volume is $15 \mathrm{~L}$ in sheep and 100 - $150 \mathrm{~L}$ in cattle [15]. Methane production arises principally from microbial fermentation of hydrolyzed carbohydrates, and is considered an energy loss for the host [6] [29]. Many factors influence ruminant $\mathrm{CH}_{4}$ production, including level of intake, type and quality of feeds, energy consumption, animal size, growth rate, level of production, genetics, and environmental temperature [15] [29]-[32].

The global atmospheric $\mathrm{CH}_{4}$ concentration increased between pre-industrial times and 2005 from approximately 0.715 parts per million (ppm) to $1.774 \mathrm{ppm}$ [23]. The 2.5 times growth in $\mathrm{CH}_{4}$ abundance over the past 300 years is largely a result of food production, waste decomposition, and fossil-fuel mining, and makes $\mathrm{CH}_{4}$ the second largest contributor after $\mathrm{CO}_{2}$ to putative human-induced warming [25]. The world atmospheric load of $\mathrm{CH}_{4}$ was $4850 \mathrm{Mt}$ (megatonnes) in 1998 year, equivalent to an average concentration of 1745 parts per billion (ppb) [33]. The concentration of $\mathrm{CH}_{4}$ in the atmosphere is thought to be increasing at a rate of $22 \mathrm{Mt}^{-}$year ${ }^{-1}$, due to the imbalance between estimated annual global emissions of $598 \mathrm{Mt}$ and removals of $576 \mathrm{Mt}$ [34]. 


\section{Methane Formation}

Methane is a colorless, odorless, inflammable, and tasteless gas that is the primary component of natural gas. Because $\mathrm{CH}_{4}$ is present naturally in the atmosphere, the general public may be exposed to very low levels when breathing in air. Methane is lighter than air and has a specific gravity of 0.554 . Methane gas density is 0.717 $\mathrm{kg} \cdot \mathrm{m}^{-3}$, melting point is $-187^{\circ} \mathrm{C}(86 \mathrm{~K})$, boiling point $-161^{\circ} \mathrm{C}(112 \mathrm{~K})$. This gas is only poorly soluble in water, but is soluble in organic solvents. Naturally occurring methane is mainly produced by the process of methanogenesis [35]. This multistep process is used by microorganisms as an energy source. The reaction is:

$$
\mathrm{CO}_{2}+8 \mathrm{H}^{+}+8 \mathrm{e}^{-} \rightarrow \mathrm{CH}_{4}+2 \mathrm{H}_{2} \mathrm{O}
$$

The final step in the process is catalyzed by the enzyme methyl-coenzyme $\mathrm{M}$ reductase.

Methane can be released into the environment during its extraction from the earth, emissions from industries, agriculture, distribution and use in residential and commercial buildings. A large quantity of the gas is released from decaying rubbish in landfill sites [36]. Methane is also stored in sediments. These $\mathrm{CH}_{4}$ hydrates in sediments have been studied as a possible future energy resource. Recent hydrate reserves have been estimated at approximately $10^{16} \mathrm{~m}^{3}$ of $\mathrm{CH}_{4}$ gas worldwide at standard temperature and pressure conditions [36]. Methane hydrates are an unusual sedimentary mineral that occurs in the continental shelf areas, permafrost regions, and marine sediments of the world. A hydrate is any chemical or mineral that contains water, bound within its chemical structure. Thus, a $\mathrm{CH}_{4}$ hydrate is an assemblage of molecular $\mathrm{CH}_{4}$ molecules that are bound within a crystal lattice formed by $\mathrm{H}_{2} \mathrm{O}$ molecules [37]. Methane released into soil or water will eventually escape into the air where it will degrade slowly in the atmosphere by sunlight [33] [38].

\subsection{Methane from Plants}

Methane is primarily emitted through anaerobic decomposition of organic matter. Recent research indicates that plants themselves may emit small amounts of $\mathrm{CH}_{4}$, although the mechanism is not currently known [39] [40]. This implies that croplands could provide an emission of $\mathrm{CH}_{4}$ under certain circumstances. Soils can emit $\mathrm{CH}_{4}$ in two ways. First, decomposition of organic matter by microorganisms in poorly aerated soils (rice paddies, wetlands) can lead to emissions of $\mathrm{CH}_{4}$ rather than $\mathrm{CO}_{2}$. Throughout the year, portions of agricultural fields can be saturated with water, creating anaerobic microsites. This may cause minimal amounts of $\mathrm{CH}_{4}$ to be emitted. However, over an entire year, agricultural soils typically are well-aerated, and $\mathrm{CH}_{4}$ is oxidized by soil microorganisms [40].

\subsection{Methane from Enteric Fermentation}

Interest in measuring enteric $\mathrm{CH}_{4}$ emissions has moved from a focus on nutritional inefficiency to one of contributing to GHG concentrations in the atmosphere and climate change [29] [41]. Measurement of $\mathrm{CH}_{4}$ emissions due to enteric fermentation must be also taken under conditions as close as possible to typical as found in farming systems.

Enteric $\mathrm{CH}_{4}$ is a by-product of ruminant digestion produced by methanogenic microorganisms Archaea in a process called fermentation or methanogenesis. The rate and type of fermentation is influenced by animal factors such as chewing, salivation and digesta kinetics [42] [43]. Cattle produce about 7 and 9 times as much $\mathrm{CH}_{4}$ as sheep and goats, respectively. Enteric $\mathrm{CH}_{4}$ is produced mainly in the rumen $(87 \%-90 \%)$ and, to a smaller extent (13\% - 10\%), in the large intestine [44] [45].

Animal releases $\mathrm{CH}_{4}$ into the atmosphere by exhaling the gas mainly through the mouth and nostrils [23]. Of the $\mathrm{CH}_{4}$ produced by enteric fermentation in the forestomach 95\% was excreted by eructation, and from $\mathrm{CH}_{4}$ produced in the hindgut $89 \%$ was found to be excreted through the breath and only $11 \%$ through the anus [44]. Work [46] recorded 3\% from the anus (from the total $\mathrm{CH}_{4}$ enteric emissions released through mouth, nostrils, and rectum). The concentration in the breath is variable with a relatively low concentration when the breath comes from the lungs and a higher concentration when the "breath" is gases belched from the forestomachs, although breath from lungs also contain absorbed $\mathrm{CH}_{4}$ and inhaled together with air [24]. In a barn or larger room the concentration will to a large extent be influenced by the air exchange, but the concentration of $\mathrm{CH}_{4}$ will be a total mix of the $\mathrm{CH}_{4}$ from breath, belch and fart [24].

The rumen ecosystem is an anaerobic environment, in which the degradation of plant material occurs in a very short time frame compared with other anaerobic ecosystems such as wetlands and estuaries, and the fer- 
mentation products are different. Some of the microbial species have coevolved with ruminants and hindgutfermenting mammals and do not exist in any other environment (e.g., rumen protozoa) [47] [48]. Digestion of feed components by the microbiota (bacteria, protozoa, fungi) results in the production of volatile fatty acids. These acids, mainly acetate, propionate, and butyrate are used by the animal as source of energy. During the process gases are also formed and their production eliminated mainly through eructation. $\mathrm{CO}_{2}$ and $\mathrm{H}_{2}$ are using to form $\mathrm{CH}_{4}$, and thus reducing the metabolic $\mathrm{H}_{2}$ produced during microbial metabolism [4] [49]. Fermentation is an oxidative process, during which reduced cofactors (NADH, NADPH, FADH) are re-oxidized (NAD-1, NADP-1, FAD-1) through dehydrogenation reactions releasing hydrogen in the rumen. As soon as produced, hydrogen is used by methanogenic archaea, a microbial group distinct from Eubacteria, to reduce $\mathrm{CO}_{2}$ into $\mathrm{CH}_{4}$ [11].

Note that enteric methane produced by ruminants is a loss of feed energy from the diet and represents inefficient utilization of the feed [23]. In addition to environmental implications, ruminant methanogenesis represents a loss of $2 \%$ to $12 \%$ of the gross energy intake [29] [47] [50] [51]. However, it was found that small amounts of $\mathrm{CH}_{4}$ are formed also in birds. Methanobrevibacter-related phylotypes have been found to be the most prevalent methanogens in the foregut and in the hindgut of the chicken of the hoatzin (Ophistocomushoatzin). The hoatzin is the only bird species to have evolved a foregut fermentation system, analogous to the rumen [13].

\subsection{Methane from Manure}

In addition to enteric (animal-derived) $\mathrm{CH}_{4}$, excreta are another source of $\mathrm{CH}_{4}$, especially when stored an aerobically [52]. Methane generated from manure from ruminant and no ruminant livestock contributes $2 \%$ and $0.4 \%$ of global $\mathrm{CH}_{4}$ and GHG emissions, respectively. In regions with low input is enteric fermentation undoubtedly the main emission source. However, in industrialized regions with high production and food processing is manure important a source of emissions [12]. Manure $\mathrm{CH}_{4}$ emissions are a larger proportion of total farm $\mathrm{CH}_{4}$ emissions in intensively managed dairy operations with manure storage systems, and much lower in extensive or grazing operations [48].

Manure emissions are relatively high in areas where manure from the dairy sector is managed in liquid systems that produce greater quantities of $\mathrm{CH}_{4}$ emissions [12]. During manure storage, $\mathrm{CH}_{4}$ is generated through a reaction similar to that of enteric fermentation. Cellulose in the manure is degraded by microbes, with products of this process serving as substrates for methanogenesis [40].

Livestock manure contains portion of organic solids such as proteins, carbohydrates and fats that are available as food and energy for growth of anaerobic bacteria. Obvious benefit from methane production could be the energy value of the gas itself. But the gas production from manure depends mainly upon the efficiency of operating system for it. Gas yield can be a certain amount of gas produced per unit of solids degraded by the anaerobic bacteria [53]. Anaerobic digestion is a natural process in which the microorganisms consume organic matter under an oxygen-free environment. It results in production of microbial biomass and greenhouse gases $\left(\mathrm{CO}_{2}\right.$ and $\mathrm{CH}_{4}$ ). The composition of volatile solids contained in manure influence the anaerobic decomposition of organic matter and the production of $\mathrm{CH}_{4}$. The manure volatile solids are mainly composed of fatty acids, proteins and carbohydrates of which fatty acids, proteins and a part of carbohydrates are easily biodegradable [54].

\subsection{Feeding Effects on Methane}

Study [55] concluded that feed intake is the superior factor of total $\mathrm{CH}_{4}$ production. The amount of enteric $\mathrm{CH}_{4}$ is mainly related to the type and amount of feed [15] [56]-[59]. Gross energy (GE) is negatively related to feeding level and dietary fat concentration and positively to diet digestibility, whereas dietary carbohydrate composition has only minor effects. As the daily feed intake increases, $\mathrm{CH}_{4}$ production also generally increases [15]. Most studies agree that dry matter intake (DMI) is the main driver of daily methane output, although methane output per kilogram of DMI decreases with increasing feeding level [60], diet digestibility, and with increasing proportions of concentrates or lipids in the diet [8] [61].

There were found higher variability in the quantity of $\mathrm{CH}_{4}$ emitted per unit of feed intake in grazing ruminants [51] [62]-[65]. The work of [66] suggests that non-grazing low forage feeding system result in the lowest enteric $\mathrm{CH}_{4}$ emissions $\cdot \mathrm{kg}^{-1}$ energy corrected milk, with about $13 \%$ less enteric $\mathrm{CH}_{4}$ compared to a high forage feeding system at the same farm. Body weight and milk yield accounted for significant proportions of variation in $\mathrm{CH}_{4}$ emissions. Both parameters were positively related to methane concentrations [67]. 
The composition of feed or the quality of forage influences $\mathrm{CH}_{4}$ production in ruminants. Digestion in the rumen is dependent on the activity of microorganisms, which need energy, nitrogen and minerals [8] [15]. Therefore, the quality of forage affects the activity of rumen microbes and $\mathrm{CH}_{4}$ production in the rumen. Forage species, forage processing, proportion of forage in the diet, and the source of the grain also influence $\mathrm{CH}_{4}$ production in ruminants. Methane production tends to decrease as the protein content of feed increases, and increases as the fiber content of feed increases [15] [29]. $\mathrm{CH}_{4}$ production was positively related to diet digestibility and negatively related to dietary fat concentration, whereas dietary carbohydrate composition had only minor effects [68]. Production of $\mathrm{CH}_{4}$ has a negative impact on animal productivity, resulting in lost energy ranging from $2 \%$ to $12 \%$ of the animal's GEI [55] [69].

\section{Methane Degradation}

Methane is removed from the atmosphere (i.e., converted to less harmful products) by a range of chemical and biological processes, which occur in different regions of the atmosphere. The degradation of $\mathrm{CH}_{4}$ in atmosphere includes tropospheric oxidation, stratospheric oxidation and uptake by soil [70].

The oxidation of $\mathrm{CH}_{4}$ in the troposphere is the largest $\mathrm{CH}_{4}$ sink, removing $506 \mathrm{Mt}$ of this gas per year from the global $\mathrm{CH}_{4}$ burden. Most of the emitted methane is slowly oxidized in the troposphere through reactions with the hydroxyl $\mathrm{OH}$ radical, although a certain fraction escapes to the stratosphere mainly in the intertropical convergence zone. Furthermore it is transported by the Brewer-Dobson circulation and oxidized through a complex series of reactions, which play an important role in increasing the stratospheric water vapor abundance [14]. Also, a small fraction of the methane is captured and oxidized in soils [71].

Stratospheric oxidation of $\mathrm{CH}_{4}$ consumes $40 \mathrm{Mt}$ per year. Approximately $30 \mathrm{Mt}$ per year of $\mathrm{CH}_{4}$ are removed annually from the atmosphere by soil uptake. Therefore, the total sinks of $\mathrm{CH}_{4}$ are estimated on $576 \mathrm{Mt}$ per year while the overall emissions are estimated on $598 \mathrm{Mt}$ of $\mathrm{CH}_{4}$ per year. Soil is an important source of sink of $\mathrm{CH}_{4}$, and it contains populations of methanotrophic bacteria that can oxidize $\mathrm{CH}_{4}$, by a process known as high affinity oxidation. These bacteria convert $\mathrm{CH}_{4}[4]$.

Although there are some differences between published estimates the average lifetime of methane in the troposphere of 9 years can be safely assumed, whereas the corresponding lifetime in the stratosphere is much shorter [14]. It has a net lifetime of about 10 years and is primarily removed by conversion to carbon dioxide and water.

\section{Amount of Methane Produced}

The atmospheric air contains a small concentration of methane (1.8 ppm), compared to respiration air of cattle (approximately $1000 \mathrm{ppm}$ ) [24]. The barn concentration of $\mathrm{CH}_{4}$ is a mixture of air from background (outdoor concentration representing atmospheric air) and gases excreted from the animal. Moreover, if manure is kept in the animal barn, some $\mathrm{CH}_{4}$ may originate from this manure [24]. Methane production is measured by many methods [72] in absolute as well as relative units, e.g. the ratio of emissions to the live weight (LW), per unit of feed intake (GE, DM), or fat and protein corrected milk (FPCM).

\subsection{Dairy Cattle and Sheep}

Authors [73] calculated enteric $\mathrm{CH}_{4}$ emission rates using a procedure that reflects the development of the calves' rumen as well as German national animal performance data and representative diet properties. Calves (birth weight of $41 \mathrm{~kg}$, final LW of $125 \mathrm{~kg}$ and a mean weight gain of $0.67 \mathrm{~kg}^{-d_{a y}}{ }^{-1}$ ) had the emission rate of $9.4 \mathrm{~kg}$ $\mathrm{CH}_{4}$ per place and year.

Methane emissions by dairy cows vary with body weight, feed intake, diet composition, and milk yield. When cows are fed the same diet at the same intake, however, variation between cows in $\mathrm{CH}_{4}$ emissions can be substantial [74]. Study [45] estimated by using the sulfur hexafluoride tracer technique adapted to collect breath samples over 5-day periods expressed methane emission in grazing dairy cows as absolute value (368 $\mathrm{g} \cdot \mathrm{day}^{-1}$ or $^{-1}$ $516{\mathrm{~L} \cdot \text { day }^{-1}}^{-1}$. Work [75] evaluated enteric $\mathrm{CH}_{4}$ emissions from 1964 Holstein cows across 21 farms for at least 7 days using $\mathrm{CH}_{4}$ analyzers at robotic milking stations. Cows were fed the same feeding systems during sampling. Methane concentrations (in milligrams per $\mathrm{L}$ of air sampled by the analyzer) were quantified in gas released by eructation during milking. The average $\mathrm{CH}_{4}$ concentration across farms was $2.9 \mathrm{mg} \cdot \mathrm{L}^{-1}$ which would equate to $418 \mathrm{~g} \cdot$ day $^{-1}$ of eructed $\mathrm{CH}_{4}$. [67] using the relationship between $\mathrm{CH}_{4}$ emission rate during milking and 
daily $\mathrm{CH}_{4}$ emissions measured in respiration chambers observed for cows on the same dietary regimen the overall mean $\mathrm{CH}_{4}$ emissions was $369 \mathrm{~g} \cdot \mathrm{d}^{-1}$ and the range was 278 to $456 \mathrm{~g} \cdot$ day $^{-1}$. Reference [40] found annual $\mathrm{CH}_{4}$ emissions calculated on livestock unit ( $\mathrm{LU}$ is $500 \mathrm{~kg}$ ) from $58 \mathrm{~kg} \cdot \mathrm{LU}^{-1}$ in dry cows to $106 \mathrm{~kg} \cdot \mathrm{LU}^{-1}$ for lactating cows. Lactating cows emit approximately twice the amount of $\mathrm{CH}_{4}$ as compared to either dry cows or heifers; this is largely due to their increased feed intake, although ration and animal size also have an effect. These emission factors may include emissions from feces deposited on the barn floor, which would be much less than emissions from enteric fermentation [40]. Authors [20] recorded annual $\mathrm{CH}_{4}$ emissions from enteric $\mathrm{CH}_{4}$ fermentation $107 \mathrm{~kg}$ for dairy cow with a milk yield of $7870 \mathrm{~kg} \cdot$ head $^{-1}$. The corresponding value for dairy ewe was $8.4 \mathrm{~kg} \cdot$ head $^{-1}$. Study [76] evaluated dairy cows fed a diet with forage: concentrate ratio of 500:500 or 900:100 $\mathrm{g} \cdot \mathrm{kg}^{-1}$ of DM of total DMI. Mean $\mathrm{CH}_{4}$ yields did not differ between diets, being 16.9 and $20.2 \mathrm{~g} \cdot \mathrm{kg}^{-1} \mathrm{DMI}$ for the 500:500 and 900:100 diets, respectively. Methane productions were 267 and $339 \mathrm{~g} \cdot \mathrm{day}^{-1} \cdot \mathrm{cow}^{-1}$, respectively. Article [46] found at the DMI of $17.5 \mathrm{~kg} \cdot \mathrm{d}^{-1}$ and milk yield of $22.9 \mathrm{~kg} \cdot \mathrm{d}^{-1} \mathrm{CH}_{4}$ measured by sulfur hexafluoride technique of $469 \mathrm{~g} \cdot \mathrm{d}^{-1}$ (292 - 647), and $\mathrm{CH}_{4}$ measured by respiration chamber $422 \mathrm{~g} \cdot \mathrm{d}^{-1}$ (275 - 577). They calculated ratios during measuring by respiration chamber technique $\mathrm{CH}_{4}$ : DMI of $24.3 \mathrm{~g} \cdot \mathrm{kg}^{-1}$ (14.1 - 29.2) and $\mathrm{CH}_{4}$ : milk yield of $19.9 \mathrm{~g} \cdot \mathrm{kg}^{-1}(6.9-54.2)$.

The study of [77] recorded from lactating and dry cows and heifers on pasture under tropical conditions, using the tracer gas technique that Holstein produced more $\mathrm{CH}_{4}\left(299.3 \mathrm{~g} \cdot \mathrm{d}^{-1}\right)$ than the Crossbred $\left(264.2 \mathrm{~g} \cdot \mathrm{d}^{-1}\right)$. Lactating cows produced more $\mathrm{CH}_{4}\left(353.8 \mathrm{~g} \cdot \mathrm{d}^{-1}\right)$ than dry cows $\left(268.8 \mathrm{~g} \cdot \mathrm{d}^{-1}\right)$ and heifers $\left(222.6 \mathrm{~g} \cdot \mathrm{d}^{-1}\right)$. Dairy cows emit approximately $430 \mathrm{~g} \cdot \mathrm{d}^{-1}$ at peak lactation down to $250 \mathrm{~g} \cdot \mathrm{d}^{-1}$ as milk yield declines [78] [79]. Holstein cows produced less $\mathrm{CH}_{4}$ per unit of dry matter intake $\left(19.1 \mathrm{~g} \cdot \mathrm{kg}^{-1}\right)$ than the Crossbred $\left(22.0 \mathrm{~g} \cdot \mathrm{kg}^{-1}\right)$. Methane emission by heifers grazing fertilized pasture was higher $\left(222.6 \mathrm{~g} \cdot \mathrm{day}^{-1}\right)$ than that of heifers on unfertilized pasture (179.2 g. day ${ }^{-1}$ ) [77]. Authors [80] measured $\mathrm{CH}_{4}$ emissions using the sulfur hexafluoride tracer technique in grazing Jersey $\times$ Friesian dairy cows in mid lactation. The average DMI was estimated to be $17.1 \mathrm{~kg} \cdot \mathrm{d}^{-1}$. Daily $\mathrm{CH}_{4}$ emissions ranged from 151 to $497 \mathrm{~g} \cdot$ day $^{-1}$ with an average of $311 \mathrm{~g} \cdot$ day $^{-1}$ or $18.2 \mathrm{~g} \cdot \mathrm{kg}^{-1} \mathrm{DMI}$.

In the [81] study, data from purebred Holstein, Simmental and Jersey cows were analyzed to test the assumption that there are genetically low methane-producing animals. Methane emission of cows offered forage ad libitum and some concentrate was measured in open-circuit respiration chambers The Holstein, Simmental and Jersey cows emitted on average $25 \mathrm{~g} \cdot \mathrm{kg} \mathrm{DMI}^{-1}, 25 \mathrm{~g} \cdot \mathrm{kg} \mathrm{DMI}^{-1}$, and $26 \mathrm{~g} \cdot \mathrm{kg} \mathrm{DMI}^{-1}$, respectively. There was no indication of individual cows with persistently low or high $\mathrm{CH}_{4}$ yield per $\mathrm{kg}$ DMI and per $\mathrm{kg}$ of milk. Authors [51] in an experiment involving 302 lactating dairy cows revealed that $\mathrm{CH}_{4}$ emissions per DMI ranged from 11 to $31 \mathrm{~g} \cdot \mathrm{kg}^{-1}$ DMI, with mean $\mathrm{CH}_{4}$ emissions from the lower and upper quartile being 16 and $23 \mathrm{~g} \cdot \mathrm{kg}^{-1} \mathrm{DMI}$, respectively. Reference [82] calculated $15.4 \mathrm{~g} \cdot \mathrm{kg}^{-1} \mathrm{FPCM}$ enteric $\mathrm{CH}_{4}$ emitted. Methane emissions expressed as absolute value are according to [45] $368 \mathrm{~g} \cdot$ day $^{-1}$ or $516 \mathrm{Ld}^{-1}$. The variation in $\mathrm{CH}_{4}$ yield remained among the animals (26.4 $\left.\pm 3.6 \mathrm{~g} \cdot \mathrm{kg}^{-1} \mathrm{DMI}\right)$. The change in $\mathrm{CH}_{4}$ yields may have resulted from lower feed intakes of lower quality pasture compared with grazing. Regression analysis showed that absolute $\mathrm{CH}_{4}$ emission (g. day ${ }^{-1}$ ) was best described by DMI and rumen acetate concentration [51].

Sometimes it is stated that increased production of methane causes bloating cows. Study [83] selected Friesian, Jersey, and Friesian $\times$ Jersey cross dairy cattle for high or low susceptibility to pasture bloat. They found that cattle with low or high bloat susceptibility are also differing in $\mathrm{CH}_{4}$ emissions. So, bloat susceptibility is a genetically inherited trait. At the research of [84], the mean absolute $\mathrm{CH}_{4}$ emissions from low bloat cows were significantly higher than from high bloat cows (144.5 vs. $107.4 \mathrm{~g} \cdot \mathrm{d}^{-1}$ and $\left.147.9 \mathrm{vs.} 119 \mathrm{~g} \cdot \mathrm{d}^{-1}\right)$ during both periods (5 or 4 consecutive measuring days). However, on per unit of $\mathrm{LW}$ basis, $\mathrm{CH}_{4}$ emissions from low and high bloat animals were not different from each other either at period 1 (346 vs. $312 \mathrm{mg} \cdot \mathrm{kg} \cdot \mathrm{LW}^{-1}$ ) or period 2 (345 vs. $\left.347 \mathrm{mg} \cdot \mathrm{kg} \cdot \mathrm{LW}^{-1}\right)$.

Primary sources of $\mathrm{CH}_{4}$ on dairy farms are not only animals but also manure storage, with smaller contributions from field-applied manure, feces deposited by grazing animals, and manure on barn floors. Reference [40] calculated in simulating representative 100-cow dairy farm annual emissions of $142 \mathrm{~kg} \mathrm{CH}_{4}$ per Holstein cow and $6.4 \mathrm{~kg} \mathrm{CH}_{4}$ per $\mathrm{m}^{3}$ of slurry manure in storage. Feed intake was the primary predictor of total $\mathrm{CH}_{4}$ production.

\subsection{Beef Cattle and Meat Sheep}

Reference [85] showed in steers of average LW $325 \mathrm{~kg}$ based on the animal-scale method, the average $\mathrm{CH}_{4}$ emission rate over 9 days $161 \pm 20 \mathrm{~g}$ - day ${ }^{-1}$. There was a significant difference between two contrasting diets (Lucerne silage diet, cereal, Lucerne, and straw mixed ration) in daily $\mathrm{CH}_{4}$ production, with mean methane pro- 
duction of $124.3 \mathrm{~g} \cdot \mathrm{day}^{-1}$ and $169.8 \mathrm{~g} \cdot \mathrm{day}^{-1}$ [86]. On average, mature beef cows emit $\mathrm{CH}_{4}$ from $240 \mathrm{~g} \cdot \mathrm{day}^{-1}$ to $350 \mathrm{~g} \cdot$ day $^{-1}$ [78] [79]. Authors [14] found that the $\mathrm{CH}_{4}$ emission rates corresponding to values of $190 \mathrm{~g} \cdot \mathrm{day}^{-1}$ per beef cattle head and [20] recorded annually $60 \mathrm{~kg} \cdot$ head $^{-1}$. The results of [87] show that daily $\mathrm{CH}_{4}$ emissions differed about $7 \%$ according to technique (185 vs. $199 \mathrm{~g} \cdot$ day $^{-1}$ per animal).

Average daily $\mathrm{CH}_{4}$ emissions were $323 \mathrm{~g} \cdot \mathrm{day}^{-1}$ per animal in feedlot. Emissions from the runoff retention pond associated directly with the feedlot operation were approximately $2.7 \mathrm{~g}$ of the daily average feedlot emissions of $\mathrm{CH}_{4}$ [69]. Animals kept in feedlots, as opposed to pasture, emit less $\mathrm{CH}_{4}$ per kilogram of weight gain due to decreased forage consumption, increased grain in the diet and decreased activity [69]. Authors [88] compared $\mathrm{CH}_{4}$ emissions from a typical feedlot in Australia and in Canada. The average $\mathrm{CH}_{4}$ emission was $166 \pm 90$ and $214 \pm 61 \mathrm{~g} \cdot$ day $^{-1}$ per animal for the feedlot in Queensland (AU) and in Alberta (CA), respectively. The lower $\mathrm{CH}_{4}$ emission at the Queensland feedlot was attributed to the lighter weight of the cattle, and consequently their lower intake, and supplementation of the diet with lipids. Authors [89] studied beef feedlots in the north (Queensland) and south (Victoria) of the Australia. The data show a range of $\mathrm{CH}_{4}$ emissions from 146 ganim$\mathrm{al}^{-1}$. day ${ }^{-1}$ in Victoria to 166 ganimal $^{-1}$. day ${ }^{-1}$ in Queensland. Values obtained in the study of [90] on feedlot cattle included both enteric $\mathrm{CH}_{4}$ and $\mathrm{CH}_{4}$ derived from the manure deposited. The $\mathrm{CH}_{4}$ emissions encompass a range from a low of $79 \mathrm{~g} \cdot \mathrm{day}^{-1}$ to a peak of $395.8 \mathrm{~g} \cdot \mathrm{day}^{-1}$ [90].

Suffolk sheep emit 22 - $25 \mathrm{~g} \cdot$ day $^{-1}$ [78] [91]. The bison's annual $\mathrm{CH}_{4}$ emissions based on calorimeter measurements at $411 \mathrm{~kg}$ of LW, $3.4 \mathrm{t}$ DMI per head and year were $72 \mathrm{~kg} \cdot \mathrm{head}^{-1}$ [92]. Reference [93] found in developed countries estimated $\mathrm{CH}_{4}$ emission rate 150.7, 137, 21.9 and $13.7\left(\right.$ ganimal ${ }^{-1}$.day ${ }^{-1}$ ) per cattle, buffaloes, sheep, and goat, respectively.

\subsection{Manure Management}

Methane production from manure management was 33.2, 2.0 and $0.3 \mathrm{~kg} \cdot \mathrm{head}^{-1} \cdot \mathrm{year}^{-1}$ for dairy cattle, beef cattle and dairy ewes [20]. Stored liquid animal manure is an important emissions source of $\mathrm{CH}_{4}$ globally [94]. Fluxes were measured from a circular concrete tank $11.25 \mathrm{~m}$ in diameter storing liquid dairy manure. Monthly average $\mathrm{CH}_{4}$ flux ranged from $11 \mu \mathrm{gm}^{-2} \cdot \mathrm{s}^{-1}$ in June after the tank had been emptied, to $153 \mu \mathrm{gm}^{-2} \cdot \mathrm{s}^{-1}$ in July [94].

It was observed that the excreta of animals grazing in the morning emitted much more $\mathrm{CH}_{4}$ than that of steers grazing in the afternoon [95]. The $\mathrm{CH}_{4}$ emission depends on the physical form of the feces (shape, size, density, humidity), the amount of digestible material, the climate (temperature and humidity) and the time they remained intact [95]-[97]. Expected amount of excreta for steers may be around $1.5-2.2 \mathrm{~kg}$ of dry matter per day, so the measured values must be $730 \mathrm{~kg} \cdot$ year $^{-1}$. Consequently, the total $\mathrm{CH}_{4}$ emission can be estimated to be from 0.012 $\mathrm{kg} \cdot$ head $^{-1} \cdot$ year $^{-1}$ to $0.067 \mathrm{~kg} \cdot$ head $^{-1} \cdot$ year $^{-1}$.

Source [2] quantified summer $\mathrm{CH}_{4}$ emissions from wastewater lagoons of a commercial dairy farm. Methane concentrations over three lagoons (total area of 1.8 ha) and background concentrations were measured. Methane concentrations in the air over the lagoons ranged from 3 to $12 \mathrm{ppm}$, and averaged $5.6 \mathrm{ppm}$, with a background $\mathrm{CH}_{4}$ concentration of $1.83 \mathrm{ppm}$. Methane flux density (emission rate. unit area ${ }^{-1}$ ) ranged from 165 to 1184 $\mathrm{g} \cdot \mathrm{m}^{-2} \cdot \mathrm{s}^{-1}$, with a mean daily flux density of $402 \mathrm{~kg} \cdot \mathrm{ha}^{-1} \cdot \mathrm{d}^{-1}$. Methane emission rate averaged 0.211 $\mathrm{kg} \cdot$ head $^{-1} \cdot$ day $^{-1}$. Reference [53] estimated the average potential $\mathrm{CH}_{4}$ production from the livestock manure, and found the production of 692, 946, 125 and $6.4 \mathrm{~cm}^{3}$ daily from dairy cattle (545 kg), beef cattle (450 kg), swine (68 kg) and poultry $(1.8 \mathrm{~kg})$, respectively.

Authors [98] measured $\mathrm{CH}_{4}$ concentrations over the pens, wastewater storage pond, and composting area on a 700-cow open-lot dairy farm. Average $\mathrm{CH}_{4}$ concentrations over the pens, storage pond, and composting area ranged from 2.07 to 2.80 parts per million by volume (ppmv), 1.87 to $2.15 \mathrm{ppmv}$, and 1.71 to $1.76 \mathrm{ppmv}$, respectively. Combined $\mathrm{CH}_{4}$ emissions for the pen and storage pond areas were $0.34,0.55,0.21$, and 0.20 $\mathrm{kg} \cdot \mathrm{cow}^{-1} \cdot$ day $^{-1}$ for the January, March, June, and September. The annual emissions from the pens and storage pond at this dairy operation were $120 \mathrm{~kg} \cdot \mathrm{cow}^{-1}$.

\section{Conclusions}

Animal husbandry is an important contributor to global emissions of greenhouse gases, in particular of methane. Enteric fermentation from livestock ruminants is a large source of methane, which has a global warming potential 23 times that of carbon dioxide. This work summarizes the current state of knowledge on methane production relevant to environmental aspects. The methane emissions in dairy cattle represent values from 26 to 497 
$\mathrm{g} \cdot$ day $^{-1}$. The average $\mathrm{CH}_{4}$ emissions are from $161 \mathrm{~g} \cdot$ day $^{-1}$ to $396 \mathrm{~g} \cdot$ day $^{-1}$ in beef cattle. Dairy ewe creates 8.4 $\mathrm{kg} \cdot \mathrm{head}^{-1}$ of $\mathrm{CH}_{4}$ annually, Suffolk sheep emit $22-25 \mathrm{~g} \cdot$ day $^{-1}$. The bison's annual $\mathrm{CH}_{4}$ emissions per year were $72 \mathrm{~kg} \cdot$ head $^{-1}$. The $\mathrm{CH}_{4}$ emission from manure depends on more factors.

An extended review revealed that more data are needed to better quantify GHG emissions from farms of ruminants. It is necessary to obtain data on $\mathrm{CH}_{4}$ emissions from housing systems and manure management. New research proposals which will measure emissions from agriculture are needed to establish typical emission ranges for dairy and beef farms and the effect of management factors on these emissions. Also knowledge about emissions from farm sheep and goats are insufficient.

\section{Acknowledgements}

This article was possible through project APVV-0632-10 of the Slovak Research and Development Agency Bratislava, Slovakia.

\section{References}

[1] Smith, K., Cumby, T., Lapworth, J., Misselbrook, T. and Williams, A. (2007) Natural Crusting of Slurry Storage as an Abatement Measure for Ammonia Emissions on Dairy Farms. Biosystems Engineering, 97, 464-471. http://dx.doi.org/10.1016/j.biosystemseng.2007.03.037

[2] Todd, R.W., Cole, N.A., Casey, K.D., Hagevoort, R. and Auvermann, B.W. (2011) Methane Emissions from Southern High Plains Dairy Wastewater Lagoons in the Summer. Animal Feed Science and Technology, 166-167, 575-580. http://dx.doi.org/10.1016/j.anifeedsci.2011.04.040

[3] Stackhouse, K.R., Pan, Y., Zhao, Y. and Mitloehner, F.M. (2011) Greenhouse Gas and Alcohol Emissions from Feedlot Steers and Calves. Journal of Environmental Quality, 40, 899-906. http://dx.doi.org/10.2134/jeq2010.0354

[4] Cassandro, M., Mele, M. and Stefanon, B. (2013) Genetic Aspects of Enteric Methane Emission in Livestock Ruminants. Italian Journal of Animal Science, 12, 450-458.

[5] Olesen, J.E., Schelde, K., Weiske, A., Weisbjerg, M.R., Asman, W.A.H. and Djurhuus, J. (2006) Modelling Greenhouse Gas Emissions from European Conventional and Organic Dairy Farms. Agriculture, Ecosystems and Environment, 112, 207-220. http://dx.doi.org/10.1016/j.agee.2005.08.022

[6] Kristensen, T, Mogensen, L., Knudsen, M.T. and Hermansen, J.E. (2011) Effect of Production System and Farming Strategy on Greenhouse Gas Emissions from Commercial Dairy Farms in a Life Cycle Approach. Livestock Science, 140, 136-148. http://dx.doi.org/10.1016/j.livsci.2011.03.002

[7] Mihina, S., Kazimirova, V. and Copland, T.A. (2012) Technology for Farm Animal Husbandry. 1st Issue, Slovak Agricultural University, Nitra, 99 p.

[8] Moss, A.R., Jouany, J. and Newbold, J. (2000) Methane Production by Ruminants: Its Contribution to Global Warming. Annales De Zootechnie, 49, 231-253. http://dx.doi.org/10.1051/animres:2000119

[9] Alemu, A.W., Ominski, K.H. and Kebreab, E. (2011) Estimation of Enteric Methane Emissions Trends (1990-2008) from Manitoba Beef Cattle Using Empirical and Mechanistic Models. Canadian Journal of Animal Science, 91, 305-321. http://dx.doi.org/10.4141/cjas2010-009

[10] Steinfeld, H. and Wassenaar, T. (2007) The Role of Livestock Production in Carbon and Nitrogen Cycles. Annual Review of Environment and Resources, 32, 271-294. http://dx.doi.org/10.1146/annurev.energy.32.041806.143508

[11] Martin, C., Doreau, M. and Morgavi, D.P. (2010) Methane Mitigation in Ruminants: From Microbe to the Farm Scale. Animal, 4, 351-365. http://dx.doi.org/10.1017/S1751731109990620

[12] Gerber, P.J., Hristov, A.N., Henderson, B., Makkar, H., Oh, J., Lee, C., et al. (2013) Technical Options for the Mitigation of Direct Methane and Nitrous Oxide Emissions from Livestock: A Review. Animal, 7, 220-234. http://dx.doi.org/10.1017/S1751731113000876

[13] St-Pierre, B. and Wright, A.D.G. (2013) Diversity of Gut Methanogens in Herbivorous Animals. Animal, 7, 49-56. http://dx.doi.org/10.1017/S1751731112000912

[14] Huarte, A., Cifuentes, V., Gratton, R. and Clausse, A. (2010) Correlation of Methane Emissions with Cattle Population in Argentine Pampas. Atmospheric Environment, 44, 2780-2786. http://dx.doi.org/10.1016/j.atmosenv.2010.03.012

[15] Shibata, M. and Terada, T. (2010) Factors Affecting Methane Production and Mitigation in Ruminants. Animal Science Journal, 81, 2-10. http://dx.doi.org/10.1111/j.1740-0929.2009.00687.x

[16] Mc Geough, E.J., Little, S.M., Janzen, H.H., McAllister, T.A., McGinn, S.M. and Beauchemin, K.A. (2012) Life-Cycle Assessment of Greenhouse Gas Emissions from Dairy Production in Eastern Canada: A Case Study. Journal of Dairy Science, 95, 5164-5175. http://dx.doi.org/10.3168/jds.2011-5229 
[17] Brask, M., Lund, P., Weisbjerg, M.R., Hellwing, A.L.F., Poulsen, M., Larsen, M.K. and Hvelplund, T. (2013) Methane Production and Digestion of Different Physical Forms of Rapeseed as Fat Supplements in Dairy Cows. Journal of Dairy Science, 96, 2356-2365. http://dx.doi.org/10.3168/jds.2011-5239

[18] Lassey, K.R. (2008) Livestock Methane Emission and Its Perspective in the Global Methane Cycle. Australian Journal of Experimental Agriculture, 48, 114-118. http://dx.doi.org/10.1071/EA07220

[19] Beauchemin, K.A. and McGinn, S.M. (2005) Methane Emissions from Feedlot Cattle Fed Barley or Corn Diets. Journal of Animal Science, 83, 653-661.

[20] Merino, P., Ramirez-Fanlo, E., Arriaga, H., del Hierro, O., Artetxe, A. and Viguria, M. (2011) Regional Inventory of Methane and Nitrous Oxide Emission from Ruminant Livestock in the Basque Country. Animal Feed Science and Technology, 166-167, 628-640. http://dx.doi.org/10.1016/j.anifeedsci.2011.04.081

[21] Beauchemin, K.A., Janzen, H.H., Little, S.M., McAllister, T.A. and McGinn, S.M. (2010) Life Cycle Assessment of Greenhouse Gas Emissions from Beef Production in Western Canada: A Case Study. Agricultural Systems, 103, 371379. http://dx.doi.org/10.1016/j.agsy.2010.03.008

[22] Hindrichsen, I.K., Wettstein, H.R., Machmüller, A. and Kreuzer, M. (2006) Methane Emission, Nutrient Degradation and Nitrogen Turnover in Dairy Cows and Their Slurry at Different Milk Production Scenarios with and without Concentrate Supplementation. Agriculture, Ecosystems and Environment, 113, 150-161. http://dx.doi.org/10.1016/j.agee.2005.09.004

[23] Chagunda, M.G.G., Römer, D.A.M. and Roberts, D.J. (2009) Effect of Genotype and Feeding Regime on Enteric Methane, Non-Milk Nitrogen and Performance of Dairy Cows during the Winter Feeding Period. Livestock Science, 122, 323-332. http://dx.doi.org/10.1016/j.livsci.2008.09.020

[24] Madsen, J., Bjerg, B.S., Hvelplund, T., Weisbjerg, M.R. and Lund, P. (2010) Methane and Carbon Dioxide Ration in Excreted Air for Quantification of the Methane Production from Ruminants. Livestock Science, 129, 223-227. http://dx.doi.org/10.1016/j.livsci.2010.01.001

[25] Lassey, K.R. (2007) Livestock Methane Emission: From the Individual Grazing Animal through National Inventories to the Global Methane Cycle. Agricultural and Forest Meteorology, 142, 120-132. http://dx.doi.org/10.1016/j.agrformet.2006.03.028

[26] Heyer, J. and Berger, U. (2000) Methane Emission from the Coastal Area in the Southern Baltic Sea. Estuarine, Coastal and Shelf Science, 51, 13-30. http://dx.doi.org/10.1006/ecss.2000.0616

[27] Marani, L. and Alvala, P. (2007) Methane Emission from Lakes and Flood Plains in Pantanal, Brazil. Atmospheric Environment, 41, 1627-1633. http://dx.doi.org/10.1016/j.atmosenv.2006.10.046

[28] Keppler, F., Hamilton, J., Brab, M. and Röckmann, T. (2006) Methane Emission from Terrestrial Plants under Aerobic Conditions. Nature, 439, 187-191. http://dx.doi.org/10.1038/nature04420

[29] Johnson, K.A. and Johnson, D.E. (1995) Methane Emissions from Cattle. Journal of Animal Science, 73, $2483-2492$.

[30] McAllister, T.A., Mathison, E. and Cheng, K.J. (1996) Dietary, Environmental and Microbiological Aspects of Methane Production in Ruminants. Canadian Journal of Animal Science, 76, 231-243. http://dx.doi.org/10.4141/cjas96-035

[31] Hegarty, R.S. (2004) Genetic Diversity in Function and Microbial Metabolism of the Rumen. Australian Journal of Experimental Agriculture, 44, 1-9.

[32] Hegarty, R.S. (2004) Genotype Differences and Their Impact on Digestive Tract Function of Ruminants: A Review. Australian Journal of Experimental Agriculture, 44, 459-467. http://dx.doi.org/10.1071/EA02148

[33] Le Corre, O. and Loubar, K. (2010) Chapter 2. Physical Properties and Combustion Features. In: Potocnik, P., Ed., Natural Gas, InTech, Morn Hill, 616 p. http://www.intechopen.com/books/natural-gas/natural-gas-physical-properties-and-combustion-features

[34] Jardine, C.N., Boardman, B., Osman, A., Vowles, J. and Palmer, J. (2003) Methane UK. Report. Environmental Change Institute, University of Oxford, Oxford, $96 \mathrm{p}$. http://www.eci.ox.ac.uk/research/energy/downloads/methaneuk/methaneukreport.pdf

[35] Hook, S.E., Wright, A.D.G. and McBride, B.W. (2010) Methanogens: Methane Producers of the Rumen and Mitigation Strategies. Archaea, 2010, Article ID: 945785. http://dx.doi.org/10.1155/2010/945785

[36] Gabitto, J.F. and Tsouris, C. (2010) Physical Properties of Gas Hydrates: A Review. Journal of Thermodynamics, 2010, Article ID: 271291. http://dx.doi.org/10.1155/2010/271291

[37] Lonero, A. (2008) How Are Methane Hydrates Formed, Preserved, and Released? Geology 340 Term Paper, University of Hawaii at Hilo, Hilo, 53-58.

[38] Friend, D.G., Ely, J.F. and Ingham, H. (1989) Thermophysical Properties of Methane. Journal of Physical and Chemical Reference Data, 18, 583-638. http://dx.doi.org/10.1063/1.555828 
[39] Keppler, F. and Röckmann, T. (2007) Methane, Plants and Climate Change. Scientific American, 296, 52-57. http://dx.doi.org/10.1038/scientificamerican0207-52

[40] Chianese, D.S., Rotz, C.A. and Richard, T.L. (2009a) Whole Farm Greenhouse Gas Emissions: A Review with Application to a Pennsylvania Dairy Farm. Applied Engineering in Agriculture, 25, 431-442. http://dx.doi.org/10.13031/2013.26895

[41] Bell, M.J., Wall, E., Russell, G., Morgan, C. and Simm, G. (2010) Effect of Breeding for Milk Yield, Diet and Management on Enteric METHANE emissions from Dairy Cows. Animal Production Science, 50, 817-826. http://dx.doi.org/10.1071/AN10038

[42] Wilson, J.R. and Kennedy, P.M. (1996) Plant and Animal Constraints to Voluntary Feed Intake Associated with Fibre Characteristics and Particle Breakdown and Passage in Ruminants. Australian Journal of Agricultural Research, 47, 199-225. http://dx.doi.org/10.1071/AR9960199

[43] Varga, G.A. and Kolver, E.S. (1997) Microbial and Animal Limitations to Fiber Digestion and Utilization. Journal of Nutrition, 127, 819-823.

[44] Murray, P.J., Moss, A., Lockyer, D.R. and Jarvis, S.C. (1999) A Comparison of Systems for Measuring Methane Emissions from Sheep. Journal of Agricultural Science, 133, 439-444. http://dx.doi.org/10.1017/S0021859699007182

[45] Dini, Y., Gere, J., Briano, C., Manetti, M., Juliarena, P., Picasso, V., et al. (2012) Methane Emission and Milk Production of Dairy Cows Grazing Pastures Rich in Legumes or Rich in Grasses in Uruguay. Animals, 2, 288-300. http://dx.doi.org/10.3390/ani2020288

[46] Muñoz, C., Yan, T., Wills, D.A., Murray, S. and Gordon, A.W. (2012) Comparison of the Sulfur Hexafluoride Tracer and Respiration Chamber Techniques for Estimating Methane Emissions and Correction for Rectum Methane Output from Dairy Cows. Journal of Dairy Science, 95, 3139-3148. http://dx.doi.org/10.3168/jds.2011-4298

[47] Benchaar, C. and Greathead, H. (2011) Essential Oils and Opportunities to Mitigate Enteric Methane Emissions from Ruminants. Animal Feed Science and Technology, 166-167, 338-355. http://dx.doi.org/10.1016/j.anifeedsci.2011.04.024

[48] Knapp, J.R., Laur, G.L., Vadas, P.A., Weiss, W.P. and Tricarico, J.M. (2014) Enteric Methane in Dairy Cattle Production: Quantifying the Opportunities and Impact of Reducing Emissions. Journal of Dairy Science, 97, 3231-3261. http://dx.doi.org/10.3168/jds.2013-7234

[49] McAllister, T.A. and Newbold, C.J. (2008) Redirecting Rumen Fermentation to Reduce Methanogenesis. Animal Production Science, 48, 7-13. http://dx.doi.org/10.1071/EA07218

[50] Boadi, D.A. and Wittenberg, K.M. (2002) Methane Production from Dairy and Beef Heifers Fed Forages Differing in Nutrient Density Using the Sulphur Hexafluoride (SF6) Tracer Gas Technique. Canadian Journal of Animal Science, 82, 201-206. http://dx.doi.org/10.4141/A01-017

[51] Pinares-Patiño, C.S., Waghorn, G.C., Machmüller, A., Vlaming, B., Molano, G., Cavanagh, A. and Clark, H. (2007) Methane Emissions and Digestive Physiology of Non-Lactating Dairy Cows Fed Pasture Forage. Canadian Journal of Animal Science, 87, 601-613. http://dx.doi.org/10.4141/CJAS06023

[52] Klevenhusen, F., Kreuzer, M. and Soliva, C.R. (2011) Enteric and Manure-Derived Methane and Nitrogen Emissions as Well as Metabolic Energy Losses in Cows Fed Balanced Diets Based on Maize, Barley or Grass Hay. Animal, 5, 450-461. http://dx.doi.org/10.1017/S1751731110001795

[53] Song, M.K., Li, X.Z., Oh, Y.K., Lee, C.K. and Hyun, Y. (2011) Control of Methane Emission in Ruminants and Industrial Application of Biogas from Livestock Manure in Korea. Asian-Australian Journal of Animal Science, 24, 130-136. http://dx.doi.org/10.5713/ajas.2011.r.02

[54] Godbout, S., Verma, M., Larouche, J.P., Potvin, L., Chapman, A.M., Lemay, S.P., Pelletier, F. and Brar, S.K. (2010) Methane Production Potential (B0) of Swine and Cattle Manures-A Canadian Perspective. Environmental Technology, 31, 1371-1379. http://dx.doi.org/10.1080/09593331003743096

[55] Ramin, M. and Huhtanen, P. (2013) Development of Equations for Predicting Methane Emissions from Ruminants. Journal of Dairy Science, 96, 2476-2493. http://dx.doi.org/10.3168/jds.2012-6095

[56] Ellis, J.L., Kebreab, E., Odongo, N.E., McBride, B.W., Okine, E.K. and France, J. (2007) Prediction of Methane Production from Dairy and Beef Cattle. Journal of Dairy Science, 90, 3456-3467. http://dx.doi.org/10.3168/jds.2006-675

[57] Beauchemin, K.A., Kreuzer, M., O’Mara, F. and McAllister, T.A. (2008) Nutritional Management for Enteric Methane Abatement: A Review. Australian Journal of Experimental Agriculture, 48, 21-27. http://dx.doi.org/10.1071/EA07199

[58] Dijkstra, J., Van Zijderveld, S.M., Apajalahti, J.A., Bannink, A., Gerrits, W.J.J., Newbold, J.R., et al. (2011) Relationships between Methane Production and Milk Fatty Acid Profiles in Dairy Cattle. Animal Feed Science and Technology, 166-167, 590-595. http://dx.doi.org/10.1016/j.anifeedsci.2011.04.042

[59] Middelaar, C.E. Van, Berentsen, P.B.M., Dijkstra, J. and De Boer, I.J.M. (2013) Evaluation of a Feeding Strategy to Reduce Greenhouse Gas Emissions from Dairy Farming: The Level of Analysis Matters. Agricultural Systems, 121, 9- 


\section{2. http://dx.doi.org/10.1016/j.agsy.2013.05.009}

[60] Grainger, C., Clarke, T., Mcginn, S.M., Auldist, M.J., Beauchemin, K.A., Hannah, M.C., et al. (2007) Methane Emissions from Dairy Cows Measured Using the Sulphur Hexafluoride $\left(\mathrm{SF}_{6}\right)$ Tracer and Chamber Techniques. Journal of Dairy Science, 90, 2755-2766. http://dx.doi.org/10.3168/jds.2006-697

[61] Beauchemin, K.A., McGinn, S.M., Benchaar, C. and Holtshausen, L. (2009) Crushed Sunflower, Flax, or Canola Seeds in Lactating Dairy Cow Diets: Effects on Methane Production, Rumen Fermentation, and Milk Production. Journal of Dairy Science, 92, 2118-2127. http://dx.doi.org/10.3168/jds.2008-1903

[62] Ulyatt, M., Lassey, K., Shelton, I. and Walker, C. (2002) Methane Emission from Dairy Cows and Wether Sheep Fed Subtropical Grass-Dominant Pastures in Midsummer in New Zealand. New Zealand Journal of Agricultural Research, 45, 227-234. http://dx.doi.org/10.1080/00288233.2002.9513513

[63] Pinares-Patiño, C.S, Ulyatt, M.J., Lassey, K.R., Barry, T.N. and Holmes, C.W. (2003) Persistence of Differences between Sheep in Methane Emission under Generous Grazing Conditions. The Journal of Agricultural Science, 140, $227-$ 233. http://dx.doi.org/10.1017/S0021859603003071

[64] Boadi, D., Benchaar, C., Chiquette, J. and Masse, D. (2004) Mitigation Strategies to Reduce Enteric Methane Emissions from Dairy Cows: Update Review. Canadian Journal of Animal Science, 84, 319-335. http://dx.doi.org/10.4141/A03-109

[65] Waghorn, G.C. and Hegarty, R.S. (2011) Lowering Ruminant Methane Emissions through Improved Feed Conversion Efficiency. Animal Feed Science and Technology, 166-167, 291-301. http://dx.doi.org/10.1016/j.anifeedsci.2011.04.019

[66] Bell, M.J., Wall, E., Simm, G. and Russell, G. (2011) Effects of Genetic Line and Feeding System on Methane Emissions from Dairy Systems. Animal Feed Science and Technology, 166-167, 699-707. http://dx.doi.org/10.1016/j.anifeedsci.2011.04.049

[67] Garnsworthy, P.C., Craigon, J., Hernandez-Medrano, J.H. and Saunders, N. (2012) Variation among Individual Dairy Cows in Methane Measurements Made on Farm during Milking. Journal of Dairy Science, 95, 3181-3189. http://dx.doi.org/10.3168/jds.2011-4606

[68] Chianese, D.S., Rotz, C.A. and Richard, T.L. (2009) Simulation of Methane Emissions from Dairy Farms to Assess Greenhouse Gas Reduction Strategies. Transactions of the ASABE, 52, 1313-1323. http://dx.doi.org/10.13031/2013.27781

[69] Haarlem Van, R.P., Desjardins, R.L., Gao, Z., Flesch, T.K. and Li, X. (2008) Methane and Ammonia Emissions from a Beef Feedlot in Western Canada for a Twelve-Day Period in The fall. Canadian Journal of Animal Science, 88, 641649. http://dx.doi.org/10.4141/CJAS08034

[70] Younglove, B.A. and Ely, J.F. (1987) Thermophysical Properties of Fluids. II. Methane, Ethane, Propane, Isobutane, and Normal Butane. Journal of Physical and Chemical Reference Data, 16, 577-798. http://dx.doi.org/10.1063/1.555785

[71] Ridgwell, A., Marshall, S. and Gregson, K. (1999) Consumption of Atmospheric Methane by Soils: A Process Based Model. Global Biogeochemical Cycles, 13, 59-70. http://dx.doi.org/10.1029/1998GB900004

[72] Broucek, J. (2014) Methods of Methane Measuring in Ruminants. Slovak Journal of Animal Science, 47, 81-90.

[73] Dämmgen, U., Meyer, U., Rösemann, C., Haenel, H.D. and Hutchings, N.J. (2013) Methane Emissions from Enteric Fermentation as Well as Nitrogen and Volatile Solids Excretions of German Calves-A National Approach. Landbauforschung-Applied Agricultural and Forestry Research, 63, 37-46.

[74] Bell, M.J. Cullen, B.R. and Eckard, R.J. (2012) The Influence of Climate, Soil and Pasture Type on Productivity and Greenhouse Gas Emissions Intensity of Modeled Beef Cow-Calf Grazing Systems in Southern Australia. Animals, 2, 540-558. http://dx.doi.org/10.3390/ani2040540

[75] Bell, M.J., Potterton, S.L., Craigon, J., Saunders, N., Wilcox, R.H., Hunter, M., et al. (2014) Variation in Enteric Methane Emissions among Cows on Commercial Dairy Farms. Animal, 9, 1540-1546. http://dx.doi.org/10.1017/S1751731114001530

[76] Danielsson, R., Schnürer, A., Arthurson, V. and Bertilsson, J. (2012) Methanogenic Population and CH4 Production in Swedish Dairy Cows Fed Different Levels of Forage. Applied and Environmental Microbiology, 78, 6172-6179. http://dx.doi.org/10.1128/AEM.00675-12

[77] Pedreira, S.M., Primavesi, O., Lima, M.A., Frighetto, R., de Oliveira, S.G. and Berchielli, T.T. (2009) Ruminal Methane Emission by Dairy Cattle in Southeast Brazil. Scientia Agricola (Piracicaba, Brazil), 66, 742-750.

[78] Eckard, R.J., Grainger, C. and de Klein, C.A.M. (2010) Options for the Abatement of Methane and Nitrous Oxide from Ruminant Production: A Review. Livestock Science, 130, 47-56. http://dx.doi.org/10.1016/j.livsci.2010.02.010

[79] Cottle, D. and Conington, J. (2013) Reducing Methane Emissions by Including Methane Production or Feed Intake in Genetic Selection Programmes for Suffolk Sheep. Journal of Agricultural Science, 151, 872-888. 
http://dx.doi.org/10.1017/S0021859612001037

[80] Cavanagh, A., McNaughton, L., Clark, H., Greaves, J.M., Gowan, J.M., Pinares-Patino, C., et al. (2008) Methane Emissions from Grazing Jersey $\times$ Friesian Dairy Cows in Mid Lactation. Australian Journal of Experimental Agriculture, 48, 230-233. http://dx.doi.org/10.1071/EA07277

[81] Münger, A. and Kreuzer, M. (2008) Absence of Persistent Methane Emission Differences in Three Breeds of Dairy Cows. Australian Journal of Experimental Agriculture, 48, 77-82. http://dx.doi.org/10.1071/EA07219

[82] Bannink, A., van Schijndel, M.W. and Dijkstra, J. (2011) A Model of Enteric Fermentation in Dairy Cows to Estimate Methane Emission for the Dutch National Inventory Report Using the IPCC Tier 3 Approach. Animal Feed Science and Technology, 166-167, 603-618. http://dx.doi.org/10.1016/j.anifeedsci.2011.04.043

[83] Pinares-Patińo, C.S. and Clark, H. (2008a) Reliability of the Sulfur Hexafluoride Tracer Technique for Methane Emission Measurement from Individual Animals: An Overview. Australian Journal of Experimental Agriculture, 48, 223229. http://dx.doi.org/10.1071/EA07297

[84] Pinares-Patińo, C.S., Molano, G., Smith, A. and Clark, H. (2008b) Methane Emissions from Dairy Cattle Divergently Selected for Bloat Susceptibility. Australian Journal of Experimental Agriculture, 48, 234-239. http://dx.doi.org/10.1071/EA07296

[85] Laubach, J., Kelliher, F.M., Knight, T.W., Clark, H., Molano, G. and Cavanagh, A. (2008) Methane Emissions from Beef Cattle-A Comparison of Paddock- and Animal-Scale Measurements. Australian Journal of Experimental Agriculture, 48, 132-137. http://dx.doi.org/10.1071/EA07256

[86] Vlaming, J.B., Lopez-Villalobos, N., Brookes, I.M., Hoskin, S.O. and Clark, H. (2008) Within- and Between-Animal Variance in Methane Emissions in Non-Lactating Dairy Cows. Australian Journal of Experimental Agriculture, 48, 124-127. http://dx.doi.org/10.1071/EA07278

[87] McGinn, S.M., Beauchemin, K.A., Flesch, T.K. and Coates, T. (2009) Performance of a Dispersion Model to Estimate Methane Loss from Cattle in Pens. Journal of Environmental Quality, 38, 1796-1802. http://dx.doi.org/10.2134/jeq2008.0531

[88] McGinn, S.M., Chen, D., Loh, Z., Hill, J., Beauchemin, K.A. and Denmead, O.T. (2008) Methane Emissions from Feedlot Cattle in Australia and Canada. Australian Journal of Experimental Agriculture, 48, 183-185. http://dx.doi.org/10.1071/EA07204

[89] Loh, Z., Chen, D., Bai, M., Naylor, T., Griffith, D., Hill, J., et al. (2008) Measurement of Greenhouse Gas Emissions from Australian Feedlot Beef Production Using Open-Path Spectroscopy and Atmospheric Dispersion Modeling. Australian Journal of Experimental Agriculture, 48, 244-247. http://dx.doi.org/10.1071/EA07244

[90] Cooprider, K.L., Mitloehner, F.M., Famula, T.R., Kebreab, E., Zhao, Y. and Van Eenennaam, A.L. (2011) Feedlot Efficiency Implications on Greenhouse Gas Emissions and Sustainability. Journal of Animal Science, 89, 2643-2656. http://dx.doi.org/10.2527/jas.2010-3539

[91] Cottle, D.J., Nolan, J.V. and Wiedemann, S.G. (2011) Ruminant Enteric Methane Mitigation: A Review. Animal Production Science, 51, 491-514. http://dx.doi.org/10.1071/AN10163

[92] Kelliher, F.M. and Clark, H. (2010) Methane Emissions from Bison-An Historic Herd Estimate for the North American Great Plains. Agricultural and Forest Meteorology, 150, 473-477. http://dx.doi.org/10.1016/j.agrformet.2009.11.019

[93] Sejian, V., Lal, R., Lakritz, J. and Ezeji, T. (2011) Measurement and Prediction of Enteric Methane Emission. International Journal of Biometeorology, 55, 1-16. http://dx.doi.org/10.1007/s00484-010-0356-7

[94] VanderZaag, A.C., Wagner-Riddle, C., Park, K.-H. and Gordon, R.J. (2011) Methane Emissions from Stored Liquid Dairy Manure in a Cold Climate. Animal Feed Science and Technology, 166-167, 581-589. http://dx.doi.org/10.1016/j.anifeedsci.2011.04.041

[95] Priano, M.E., Fuse, V.S., Ger, J.I., Berkovic, A.M., Williams, K.E., Guzman, S.A., Gratton, R. and Juliarena, M.P. (2014) Strong Differences in the $\mathrm{CH}_{4}$ Emission from Feces of Grazing Steers Submitted to Different Feeding Schedules. Animal Feed Science and Technology, 194, 145-150. http://dx.doi.org/10.1016/j.anifeedsci.2014.04.011

[96] González-Avalos, E. and Ruiz-Suárez, L.G. (2001) Methane Emission Factors from Cattle Manure in México. Bioresource Technology, 80, 63-71. http://dx.doi.org/10.1016/S0960-8524(01)00052-9

[97] Saggar, S., Bolan, N.S., Bhandral, R., Hedley, C.B. and Luo, J. (2004) A Review of Emissions of Methane, Ammonia and Nitrous Oxide from Animal Excreta Deposition and Farm Effluent Application in Grazed Pastures. New Zealand Journal of Agricultural Research, 47, 513-544. http://dx.doi.org/10.1080/00288233.2004.9513618

[98] Bjorneberg, D.L., Leytem, A.B., Westermann, D.T., Griffiths, P.R., Shao, L. and Pollard, M.J. (2009) Measurement of Atmospheric Ammonia, Methane, and Nitrous Oxide at a Concentrated Dairy Production Facility in Southern Idaho Using Open-Path FTIR Spectrometry. Transactions of the ASABE, 52, 1749-1756.

http://dx.doi.org/10.13031/2013.29137 
Scientific Research Publishing (SCIRP) is one of the largest Open Access journal publishers. It is currently publishing more than 200 open access, online, peer-reviewed journals covering a wide range of academic disciplines. SCIRP serves the worldwide academic communities and contributes to the progress and application of science with its publication.

Other selected journals from SCIRP are listed as below. Submit your manuscript to us via either submit@scirp.org or Online Submission Portal.
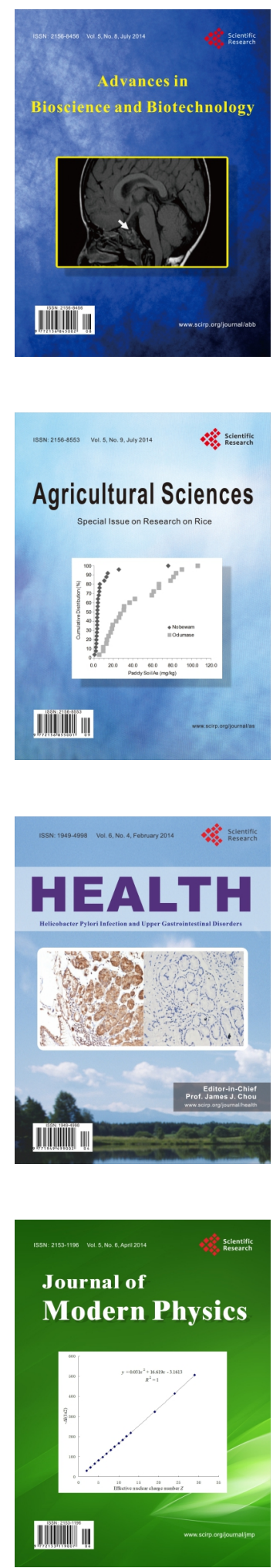
